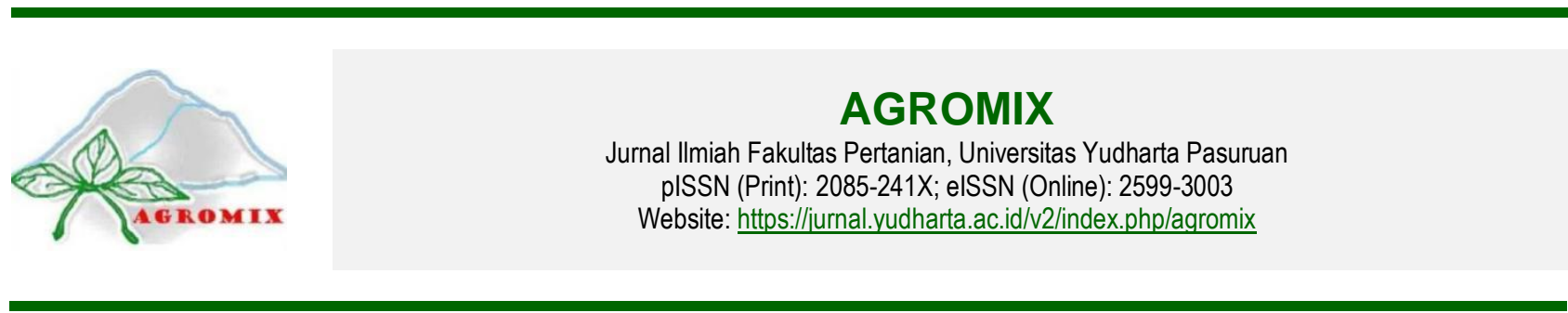

\title{
Transformasi petani madu menjadi agripreneur di Kabupaten Sumbawa
}

\author{
Transformation of honey farmers into agripreneurs in Sumbawa Regency
}

\author{
Sude Aletheia Sitorus ${ }^{1 *}$, I Nyoman Gede Ustriyana ${ }^{1}$, Gede Mekse Korri Arisena ${ }^{1}$ \\ ${ }^{1}$ Program Studi Agribisnis, Fakultas Pertanian, Universitas Udayana, Bali \\ *Email Korespondensi: theiasit3@gmail.com
}

\section{Article History \\ Received : October 23, 2020 \\ Accepted : February 02, 2021 \\ Published : March 30, 2021}

Keyword

Agripreneur; PLS; transformation of honey farmers

\section{ABSTRACT}

This study aims to analyze the characteristics of honey farmers who have become agripreneurs and analyze the influence of attitudes, subjective norms, behavioral control, and entrepreneurship education on the transformation of honey farmers into agripreneurs in Sumbawa Regency. The number of samples of respondents was 34 respondents who were obtained based on the saturated sample method. The model was designed based on the approach Structural Equation Modeling (SEM) based on Smart PLS version 3.0 which was analyzed through a computer program. The results showed that behavioral control and entrepreneurship education had a significant effect on the transformation of honey farmers into agripreneurs in Sumbawa Regency. Therefore, behavioral control which contains encouragement from family, relatives, motivators, and themselves to build a business needs to be improved, and also increasing entrepreneurial education activities containing seminars and entrepreneurship training is also very much needed by honey farmers to be able to transform into agripreneurs.

\section{Riwayat Artikel}

Dikirim : 23 Oktober 2020

Disetujui : : 02 Pebruari 2021

Diterbitkan : 30 Maret 2021

Kata Kunci

Agripreneur; PLS; transformasi petani madu

\section{ABSTRAK}

Penelitian ini bertujuan untuk menganalisis karakteristik petani madu yang sudah menjadi agripreneur dan menganalisis pengaruh sikap, norma subjektif, kontrol perilaku, dan pendidikan kewirausahaan terhadap transformasi petani madu menjadi agripreneur di Kabupaten Sumbawa. Jumlah sampel responden adalah 34 responden yang diperoleh berdasarkan metode sampel jenuh. Model dirancang berdasarkan pendekatan Structural Equation Modelling (SEM) berbasis Smart PLS versi 3.0 yang dianalisis melalui program komputer. Hasil penelitian menunjukkan bahwa kontrol perilaku dan pendidikan kewirausahaan berpengaruh signifikan terhadap transformasi petani madu menjadi agripreneur di Kabupaten Sumbawa. Oleh karena itu, kontrol perilaku yang berisi dorongan dari keluarga, kerabat, motivator, dan diri sendiri untuk membangun bisnis perlu untuk ditingkatkan, dan juga memperbanyak kegiatan pendidikan kewirausahaan yang berisi seminar dan pelatihan kewirausahaan juga sangat dibutuhkan oleh para petani madu untuk bisa bertransformasi menjadi agripreneur.

Sitasi: Sitorus, S. A., Ustriyana, I. N. G., \& Arisena, G. M. K. (2021). Transformasi petani madu menjadi agripreneur di Kabupaten Sumbawa. Agromix, 12(1), 33-38. https://doi.org/10.35891/agx.v12i1.2426

\section{PENDAHULUAN}

Pembangunan bidang pertanian yang berkelanjutan memerlukan pengembangan kewirausahaan dan juga kompetensi petani (Phelan \& Sharpley, 2012; Bosworth \& McElwee, 2014). Jumlah petani Indonesia yang semakin menurun dari tahun ke tahun menjadi bukti bahwa agripreneur saat ini belum menguntungkan, padahal Indonesia adalah negara pertanian yang memiliki segudang potensi alam yang belum teroptimalkan (Farhana, 2017).

Pembangunan ekonomi di Indonesia harus ditingkatkan dengan memanfaatkan keunggulan sumber daya hutan yang ada seperti lebah penghasil madu sehingga dapat menjadi keunggulan bersaing dan bisa menjadi pendorong bagi pertumbuhan perekonomian nasional secara umum untuk meningkatkan pendapatan serta taraf hidup masyarakat Indonesia (Nurrahmi dkk., 2018)

Potensi sumber daya hutan yang cukup luas di Indonesia membuat Indonesia memiliki keunggulan dibandingkan negara lain. Pembangunan ekonomi di Indonesia harus ditingkatkan dengan memanfaatkan keunggulan sumber daya hutan yang ada seperti lebah penghasil madu (Zulaifah, 2006).

Kabupaten Sumbawa, Provinsi Nusa Tenggara Barat dengan luas 664.398 Ha merupakan salah satu wilayah yang cukup penting bagi upaya pelestarian keanekaragaman hayati di Nusa Tenggara (Kementerian Kehutanan, 2012). Salah satu potensi alam yang dikembangkan di Kabupaten Sumbawa adalah lebah penghasil madu. 
Potensi madu alam Sumbawa sudah menjadi ikon NTB dan terkenal secara nasional. Transformasi yang cukup signifikan terjadi terhadap pendapatan para petani madu di Kabupaten Sumbawa, setelah mereka memperbaiki cara penanganan pasca panen dan juga teknik pemasaran yang mereka lakukan. "Para petani madu melakukan pengemasan produk dengan menarik dan juga menjual produknya tidak hanya di pulau Sumbawa saja tetapi juga di berbagai daerah di Indonesia, bahkan beberapa petani madu melakukan ekspor ke negara Singapura dan Malaysia, kemudian juga para agripreneur madu memasarkan produknya secara online melalui facebook, shopee, ataupun tokopedia" (Bantolo, 2020). Keinginan besar yang dimiliki para petani madu hutan untuk mengembangkan target pasarnya ternyata membuahkan hasil karena besarnya minat untuk berusaha dan juga pengetahuan baru yang diterima dari Dinas Kehutanan NTB dan JMHS (Jaringan Madu Hutan Sumbawa). Pada tahun 2017, para petani madu di Kabupaten Sumbawa menghasilkan madu sebanyak 9 ton dengan harga jual madu Rp. 130.000/kg (Junaidi, 2018). Beberapa petani madu hutan di Sumbawa bisa dikatakan sudah bertransformasi menjadi seorang agripreneur yang tetap terus menjaga kualitas produknya. Madu Sumbawa merupakan madu yang banyak diminati banyak orang, di mana diketahui terdapat berbagai ragam khasiat yang terkandung di dalam madu Sumbawa (Handrianto, 2017).

Penelitian-penelitian yang berkaitan dengan pengembangan kompetensi kewirausahaan dan organisasi pada petani di Indonesia sebagai negara berkembang khususnya masih sangat kurang. Meskipun dalam penelitian di beberapa negara maju menunjukkan bahwa aspek kewirausahaan ini sangat penting dalam pembangunan pertanian, terutama dalam hal strategi bisnis, kemampuan wirausaha petani, perilaku asosiatif petani dan organisasi petani (Bruton dkk., 2008). Petani masa kini dituntut memiliki jiwa kewirausahaan dan juga kemampuan manajemen usaha yang baik sehingga memiliki daya saing yang tinggi untuk menghadapi perubahan yang terjadi dalam dunia bisnis pertanian.

Pendidikan kewirausahaan dan lingkungan berpengaruh positif terhadap minat berwirausaha mahasiswa (Taufik, 2018). Jumlah wirausaha yang relatif besar sebanyak 325 orang di Desa Ciburuy memengaruhi petani-petani di wilayah tersebut untuk memiliki kegiatan wirausahawan di bidang pertanian (Ningsih, 2014).

Agribisnis sebagai sektor potensial di Indonesia belum dikembangkan sepenuhnya menjadi sektor utama dalam menggerakkan pembangunan ekonomi nasional (Turniasih \& Dewi, 2016). Data dari Kementerian Koperasi dan UMKM (2018) menyatakan bahwa rasio wirausaha di Indonesia terbaru sudah meningkat menjadi $7 \%$ lebih dari total penduduk Indonesia, namun menurut Badan Ekonomi Kreatif dan Badan Pusat Statistik (2017) ternyata usaha kuliner dan fashion menempati urutan pertama pada peningkatan jumlah entrepreneur yang mendominasi jumlah entrepreneur tersebut. Hal ini mengindikasikan bahwa entrepreneur yang berada dalam trend meningkat tersebut bukanlah berasal dari sektor agribisnis. Oleh karena itu Indonesia membutuhkan banyak aktor kewirausahaan dalam sektor pertanian, khususnya agripreneur.

Penelitian ini bertujuan untuk menganalisis karakteristik petani madu yang sudah menjadi agripreneur dan menganalisis pengaruh sikap, norma subjektif, kontrol perilaku, dan pendidikan kewirausahaan terhadap transformasi petani madu menjadi agripreneur di Kabupaten Sumbawa.

\section{METODE}

\section{Lokasi dan waktu penelitian}

Penelitian ini dilaksanakan di Kabupaten Sumbawa Provinsi Nusa Tenggara Barat, pada bulan Agustus sampai dengan September 2020.

\section{Metode dan teknik analisis data}

Penelitian dilaksanakan menggunakan metode wawancara yang dipandu dengan kuesioner. Populasi dalam penelitian ini berjumlah 34 orang responden. Metode penentuan sampel yang digunakan dalam penelitian ini adalah metode sampel jenuh. Metode sampel jenuh adalah teknik penentuan sampel bila semua anggota populasi digunakan menjadi sampel. Istilah lain dari sampel jenuh adalah sensus. Selain itu, jumlah tersebut telah memenuhi syarat minimal 30 dan maksimal 100 sampel dalam analisis SEM yang menggunakan program Smart-PLS (Chin dkk., 2002).

\section{Variabel penelitian dan metode analisis data}

Terdapat empat variabel dalam penelitian ini yaitu sikap $\left(X_{1}\right)$, norma subjektif $\left(X_{2}\right)$, kontrol perilaku $\left(X_{3}\right)$, pendidikan kewirausahaan $\left(\mathrm{X}_{4}\right)$, dan transformasi petani menjadi agripreneur $\left(\mathrm{Y}_{1}\right)$. Pada penelitian ini diukur rentang skor skala likert yaitu: (1) Sangat tidak setuju, (2) Tidak setuju, (3) Netral, (4) Setuju, dan (5) Sangat setuju. Semakin tinggi skor tersebut semakin tinggi juga transformasi petani menjadi agripreneur.

Metode analisis dalam penelitian ini dengan menggunakan analisis deskriptif dan juga analisis structural equation modeling (SEM). Hasil data kuesioner mengenai karakteristik responden dikelompokkan berdasarkan jawaban yang sama dan disajikan dalam bentuk tabulasi deskriptif yang telah dipersentasekan. Pengujian statistik dan uji hipotesis dianalisis dengan menggunakan software Smart PLS versi 3.0. PLS (Partial Least Square) yang merupakan model persamaan struktural (SEM) berbasis varian yang secara simultan dapat melakukan pengujian model pengukuran sekaligus pengujian model struktural (Jaya, 2008). 


\section{Metode pengambilan keputusan}

Tabulasi data dilakukan terhadap data yang diperoleh dari kuesioner dengan menggunakan Microsoft Office Excel, kemudian untuk menguji hipotesis digunakan alat uji statistik yaitu Model Persamaan Struktural (Structural Equation Model - SEM) berbasis variance atau yang lebih dikenal dengan Partial Least Square (PLS). Besar kecilnya pengaruh dari variabel laten eksogen terhadap variabel laten endogen dapat diketahui dari hasil pengolahan data menggunakan Smart PLS (Sholiha \& Salamah, 2015).

\section{HASIL DAN PEMBAHASAN}

\section{Karakteristik responden}

Karakteristik responden pada penelitian ini dibedakan berdasarkan jenis kelamin responden yang mayoritas adalah laki-laki dan berusia produktif antara 23-52 tahun. Tingkat pendidikan para petani madu yang sudah menjadi agripreneur terbanyak pada tingkat SMA. Lama usaha yang sudah dijalankan oleh para responden mayoritas berkisar antara 11-15 tahun.

\section{Analisis data}

\section{Evaluasi model pengukuran (outer model)}

Pengukuran terhadap outer model Partial Least Square (PLS) digunakan untuk mengetahui validitas dan reliabilitas indikator- indikator yang mengukur variabel laten (Tedjo \& Santoso, 2017). Kriteria uji validitas pada sebuah penelitian mengacu pada besaran outer loading setiap indikator terhadap variabel latennya (Ghozali, 2011). Diagram jalur pengolahan data dapat dilihat pada Gambar 1.

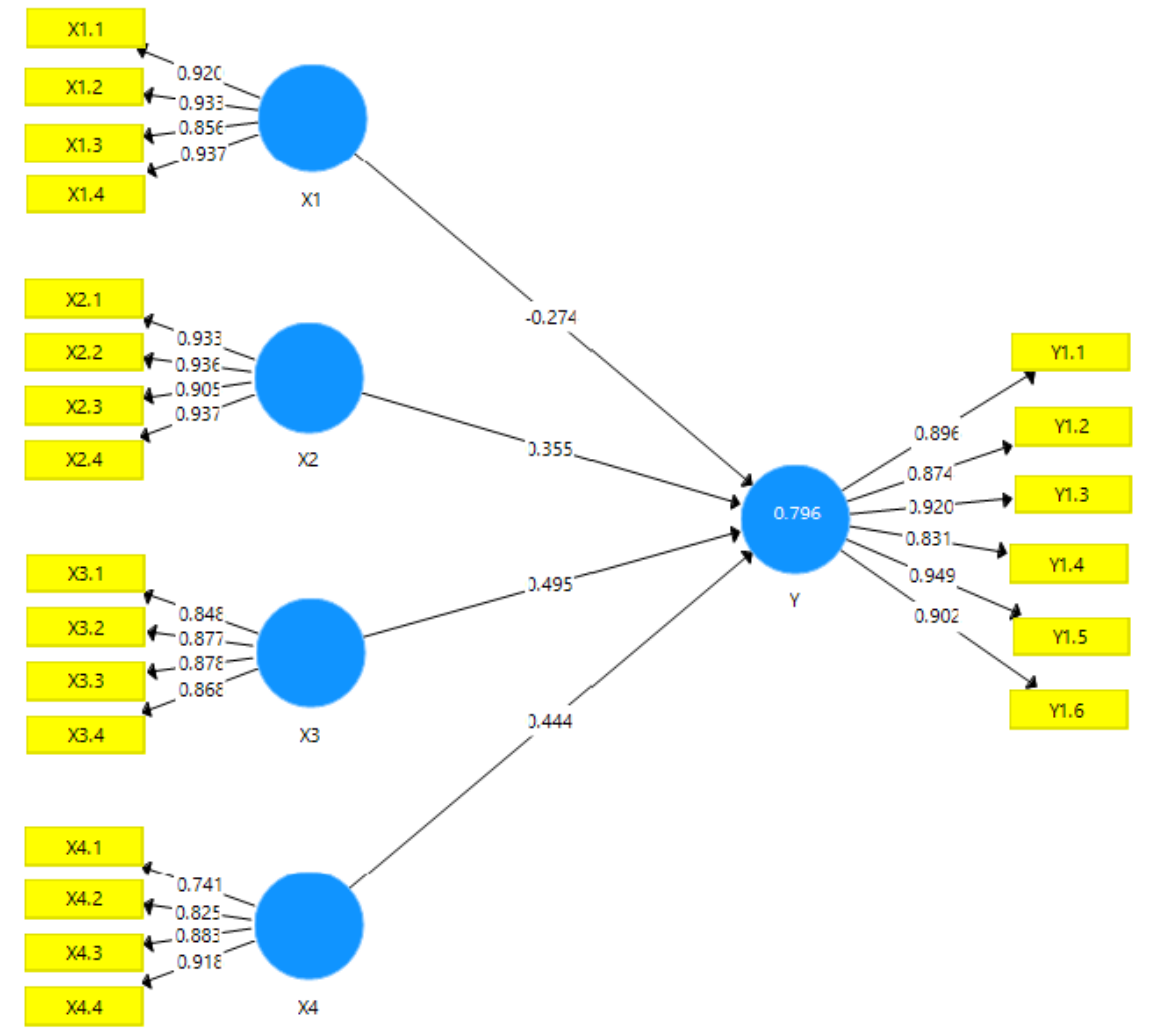

Gambar 1. Hasil outer model transformasi petani madu menjadi agripreneur di kabupaten Sumbawa

Hasil outer model pada Gambar 1 menunjukkan bahwa terdapat 22 indikator yang memiliki loading factor $>0,7$. Nilai tersebut menunjukkan korelasi antara indikator dengan variabel laten

1. Pengujian validitas model

a. Pengujian pada convergent validity yaitu dengan mengetahui nilai average variance extracted (AVE). AVE merupakan hasil dari pengukuran banyaknya varians yang dapat ditangkap dari konstruknya dibandingkan dengan varians yang dihasilkan akibat kesalahan pengukuran (Kock \& Lynn, 2012; Septiari, 2020). Variabel dikatakan valid apabila memiliki nilai AVE lebih dari 0,5 (Zaiţ \& Bertea, 2011; Garson, 2016). Berdasarkan analisis, diketahui bahwa nilai AVE sikap, norma subjektif, kontrol perilaku, pendidikan kewirausahaan, dan transformasi petani madu menjadi agripreneur > 0,5. Dapat dinyatakan bahwa semua variabel tersebut valid. 
b. Uji discriminant validity menggunakan nilai cross loading. Suatu indikator dinyatakan memenuhi discriminant validity apabila nilai cross loading indikator pada variabelnya adalah yang terbesar dibandingkan pada variabel lainnya (Sarstedt dkk., 2017). Diketahui bahwa setiap indikator memiliki cross loading lebih dari 0,7 untuk variabel laten yang diukur dibandingkan dengan indikator variabel lainnya. Indikator pada sikap, norma subjektif, kontrol perilaku, pendidikan kewirausahaan, transformasi petani madu menjadi agripreneur memiliki korelasi yang lebih besar pada laten sendiri daripada korelasi ke laten lainnya, sehingga model memenuhi syarat discriminant validity.

2. Pengujian reliabilitas model

Dilakukan juga uji reliabilitas konstruk yang diukur dengan cronbach's alpha dan composite reliability dari blok indikator yang mengukur konstruk. Konstruk dinyatakan reliabel jika memiliki nilai composite reliability dan cronbach's alpha di atas 0,7 (Irwan \& Adam, 2015).

Tabel 1. Reliabilitas transformasi petani madu menjadi agripreneur di kabupaten Sumbawa

\begin{tabular}{|c|c|c|}
\hline Variabel Laten & Cronbach's Alpha & Composite Reliability \\
\hline Sikap & 0,933 & 0,952 \\
\hline Norma Subjektif & 0,946 & 0,961 \\
\hline Kontrol Perilaku & 0,891 & 0,924 \\
\hline Pendidikan Kewirausahaan & 0,872 & 0,908 \\
\hline Transformasi Petani Madu menjadi Agripreneur & 0,951 & 0,961 \\
\hline
\end{tabular}

Berdasarkan Tabel 1, semua konstruk memiliki nilai composite reliability dan cronbach's alpha di atas 0,7 . Jadi dapat disimpulkan hasil analisis menunjukkan bahwa konstruk memiliki reliabilitas yang baik.

\section{Analisis evaluasi model struktural (inner model)}

Inner model atau model struktural merupakan pengukuran untuk menentukan hubungan atau korelasi antara konstruk dengan konstruk lainnya (Kline, 2016).

\section{Penilaian $R$-square}

Coefficient determination ( $R$-Square) digunakan untuk mengukur seberapa banyak variabel endogen dipengaruhi oleh variabel lainnya (Newman \& Japarianto, 2014). Hasil $R$-square sebesar 0,67 ke atas untuk variabel laten endogen dalam model struktural, mengindikasikan pengaruh variabel eksogen (sikap, norma subjektif, kontrol perilaku, pendidikan kewirausahaan) terhadap variabel endogen (transformasi petani madu menjadi agripreneur) termasuk dalam kategori baik. Berdasarkan hasil analisis $R$-square untuk variabel endogen transformasi petani madu menjadi agripreneur memiliki nilai sebesar 0,796. Perolehan nilai tersebut menjelaskan bahwa persentase besarnya transformasi petani madu menjadi agripreneur dapat dijelaskan oleh sikap, norma subjektif, kontrol perilaku, dan pendidikan kewirausahaan sebesar $79,6 \%$.

\section{Penilaian path coefficient}

Berdasarkan olah data yang telah dilakukan, hasilnya dapat digunakan untuk menjawab hipotesis pada penelitian ini. Uji hipotesis pada penelitian ini dilakukan dengan melihat nilai $t$-Statistics dan nilai $P$-Values. Hipotesis penelitian dapat dinyatakan diterima apabila nilai $P$-Values $<0,05$ (Ikhsania, 2015).

Tabel 2. Path coefficient transformasi petani madu menjadi agripreneur di kabupaten Sumbawa

\begin{tabular}{ccccc}
\hline & Original Sample (O) & $\begin{array}{c}\text { Standard Deviation } \\
\text { (STDEV) }\end{array}$ & $\begin{array}{c}\text { TStatistics } \\
\text { (|O/STDEV|) }\end{array}$ & $P$ Values \\
\hline X1->Y & $-0,274$ & 0,179 & 1,531 & 0,126 \\
X2->Y & 0,355 & 0,232 & 1,526 & 0,128 \\
X3->Y & 0,495 & 0,215 & 2,299 & 0,022 \\
X4->Y & 0,444 & 0,159 & 2,793 & 0,005 \\
\hline
\end{tabular}

Berdasarkan hasil bootstrapping pada Tabel 2 menunjukkan bahwa variabel kontrol perilaku (X3) memiliki pengaruh yang signifikan (t-statistik $>$ t-tabel yaitu 1,96 serta $p$-value $<0,05$ ) terhadap transformasi petani madu menjadi agripreneur (Y). Hasil penelitian ini sejalan dengan studi yang dilakukan oleh Yustina (2016) yang membuktikan bahwa kontrol perilaku berpengaruh positif dan signifikan terhadap intensi untuk berwirausaha. Semakin tinggi kepercayaan pada diri sendiri dan kemampuan serta kematangan mental, maka minat untuk berwirausaha juga semakin tinggi. Menjadi seorang wirausaha dibutuhkan kemampuan dan kepercayaan diri yang tinggi supaya dapat melewati rintangan atau hambatan yang ada.

Tabel 2 juga menunjukkan bahwa pendidikan kewirausahaan (X4) memiliki pengaruh yang signifikan signifikan (t-statistik > t-tabel yaitu 1,96 serta $p$-value $<0,05$ ) terhadap transformasi petani madu menjadi agripreneur $(\mathrm{Y})$. Hasil penelitian ini sejalan dengan studi yang membuktikan bahwa pendidikan kewirausahaan berpengaruh positif dan signifikan terhadap niat untuk berwirausaha. Semakin tinggi usaha sadar yang dilakukan individu untuk menambah wawasan tentang kewirausahaan, maka semakin besar niat individu tersebut untuk menjadi seorang wirausaha. 


\section{Pengujian hipotesis}

1. Pengaruh sikap terhadap transformasi petani madu menjadi agripreneur di kabupaten Sumbawa.

Berdasarkan hasil pengolahan data variabel sikap memiliki nilai original sample sebesar -0,274 yang artinya variabel sikap tidak berpengaruh positif sebesar $-27,4 \%$ terhadap variabel transformasi petani madu menjadi agripreneur. Variabel sikap juga tidak berpengaruh signifikan dilihat dari nilai $p$-value sebesar 0,126 $>0,05$. Sehingga berdasarkan uraian di atas maka hipotesis $\mathrm{H}_{0}$ ditolak dan $\mathrm{H}_{1}$ ditolak.

2. Pengaruh norma subjektif terhadap transformasi petani madu menjadi agripreneur di kabupaten Sumbawa.

Berdasarkan hasil pengolahan data variabel laten eksogen memiliki nilai original sample sebesar 0,355 yang artinya variabel norma subjektif berpengaruh positif sebesar 35,5\% terhadap transformasi petani madu menjadi agripreneur. Meskipun berpengaruh positif namun variabel norma subjektif tidak berpengaruh signifikan dilihat dari nilai $p$-value sebesar 0,128 > 0,05. Sehingga berdasarkan uraian di atas maka hipotesis $\mathrm{H}_{0}$ diterima $\mathrm{H}_{2}$ ditolak.

\section{Pengaruh kontrol perilaku terhadap transformasi petani madu menjadi agripreneur di kabupaten Sumbawa.}

Berdasarkan hasil pengolahan data variabel laten eksogen norma subjektif berpengaruh signifikan terhadap variabel endogen transformasi petani madu menjadi agripreneur dengan nilai t-statistik sebesar 2,299 lebih besar dari nilai (t-tabel signifikansi $5 \%=1,96$ ). Variabel kontrol perilaku berpengaruh terhadap transformasi petani madu menjadi agripreneur dan memiliki nilai positif sebesar 0,495, yang berarti mencerminkan norma subjektif berpengaruh terhadap transformasi petani madu menjadi agripreneur sebesar 49,5\%.

4. Pengaruh pendidikan kewirausahaan terhadap transformasi petani madu menjadi agripreneur di kabupaten Sumbawa.

Berdasarkan hasil pengolahan data variabel laten eksogen pendidikan kewirausahaan berpengaruh signifikan terhadap variabel endogen transformasi petani madu menjadi agripreneur dengan nilai t-statistik sebesar 2,793 lebih besar dari nilai (t-tabel signifikansi $5 \%=1,96$ ). Variabel pendidikan kewirausahaan berpengaruh terhadap transformasi petani madu menjadi agripreneur dan memiliki nilai positif sebesar 0,444 , yang berarti mencerminkan pendidikan kewirausahaan berpengaruh terhadap transformasi petani madu menjadi agripreneur sebesar 44,4\%.

Berdasarkan pengujian hipotesis terhadap pendidikan kewirausahaan tersebut dapat diketahui bahwa semakin banyak pengalaman dalam mengikuti seminar kewirausahaan, mengikuti pelatihan kewirausahaan, dan upaya yang besar untuk mengembangkan pengetahuan tentang kewirausahaan yang dimiliki, maka semakin besar minat petani madu untuk bertransformasi menjadi agripreneur.

\section{KESIMPULAN}

Kesimpulan yang dapat diambil dari hasil analisis dan pembahasan adalah karakteristik responden (petani madu yang sudah menjadi agripreneur) berdasarkan jenis kelamin mayoritas adalah laki-laki dan berusia produktif antara 2352 tahun. Tingkat pendidikan para petani madu yang sudah menjadi agripreneur terbanyak ditingkat SMA. Lama usaha yang sudah dijalankan oleh para responden mayoritas berkisar antara 11-15 tahun.

Kontrol perilaku berpengaruh positif dan signifikan terhadap transformasi petani madu menjadi agripreneur di kabupaten Sumbawa, yang berarti bahwa semakin tinggi kontrol perilaku yang dimiliki petani madu, maka akan diikuti dengan semakin meningkatnya upaya yang dilakukan petani madu tersebut untuk bisa bertransformasi menjadi agripreneur. Pendidikan kewirausahaan berpengaruh positif dan signifikan terhadap transformasi petani madu menjadi agripreneur di kabupaten Sumbawa, yang berarti bahwa semakin banyak pengetahuan tentang pendidikan kewirausahaan yang dimiliki petani madu, maka semakin besar minat petani madu untuk bertransformasi menjadi agripreneur.

\section{DAFTAR PUSTAKA}

Bosworth, G., \& McElwee, G. (2014). Agri-tourism in recession. Journal of Rural and Community Development, 3(17), 62-77.

Chin, W. W., Marcolin, B. L., \& Newsted, P. R. (2002). A partial least squares latent variable modeling approach for measuring interaction effects: results from a monte carlo simulation study and voice mail emotion/adoption study. $A$ Partial Least Squares Latent Variable Modeling Approach, 1(22), 21-40. https://doi.org/10.1287/isre.14.2.189.16018

Farhana, L. E. (2017). Optimalisasi peran agripreneurship di era mea demi mewujudkan pertanian Indonesia yang mendunia. Diakses pada 5 Mei 2020, dari https://mylindaekafblog.wordpress.com/

Garson, G. D. (2016). Partial least squares. North Carolina: Statistical Publishing Associates.

Ghozali, I. (2011). Structural equation modeling metode alternatif dengan partial least square. Semarang: Universitas Diponegoro. 
Ikhsania, Z. (2015). Pengaruh implementasi internal marketing terhadap kinerja melalui kepuasan tenaga kependidikan di fakultas ekonomi dan bisnis universitas brawijaya malang. Jurnal IImiah Administrasi Publik, 1(2), 59-69. https://doi.org/10.21776/ub.jiap.2015.001.02.9

Irwan \& Adam, K. (2015). Metode partial least square (pls) dan terapannya. Jurnal Teknosains, 9(1), 53-68.

Jaya, I. G. N. M, \& Sumertajaya, I. M. (2008). Pemodelan persamaan struktural dengan partial least square. Semnas Matematika dan Pendidikan Matematika, 1(1), 118-132.

Kementerian Kehutanan. (2012). Rencana Pengelolaan KPHP Batulanteh. Sumbawa: Kesatuan Pengelolaan Hutan Produksi Batulanteh.

Kline, R. B. (2016). Principles and practice of structural equation modeling. New York: The Guilford Press.

Kock, N., \& Lynn, G. (2012). Lateral Collinearity and Misleading Results in Variance-Based SEM: An Illustration and Recommendations. Journal of the Association for Information Systems, 13(7), 1-40. https://papers.ssrn.com/abstract=2152644

Newman, A., \& Japarianto, E. (2014). Pengaruh motivation terhadap purchase intention dengan perception sebagai variabel intervening di toko obat tradisional ban seng tong Surabaya. Jurnal Manajemen Pemasaran Petra, 2(1), $1-9$.

Ningsih, D. L. (2014). Model pengembangan kewirausahaan petani dan faktor yang mempengaruhi adopsi inovasi sistem pertanian terintegrasi padi ternak ruminansia [Thesis], Institut Pertanian Bogor.

Nurrahmi, M., Saepudin, R., Zain, B. (2018). Strategi pemasaran madu hutan di kota Bengkulu. Jurnal Sain Peternakan Indonesia, 13(2), 157-171.

Phelan, C., \& Sharpley, R. (2012). Exploring entrepreneurial skills and competencies in farm tourism. Local Economy, 27(2), 103-118. https://doi.org/10.1177/0269094211429654

Sarstedt, M., Ringle, C. M., \& Hair, J. F. (2017). Partial least squares structural equation modeling. Hamburg: Springer International Publishing.

Septiari, R. (2020). Analisis faktor-faktor yang mempengaruhi tingkat kelelahan pada pekerjaan berulang di industri manufaktur. Mekanika: Majalah Ilmiah Mekanika, 19(1), 15-21.

Sholiha, E., U., N., \& Salamah, M. (2015). Structural equation modeling-partial least square untuk pemodelan derajat kesehatan kabupaten/kota di jawa timur. Jurnal Sains dan Seni ITS, 4(2), 170-174.

Taufik, A. (2018). Faktor yang mempengaruhi minat berwirausaha mahasiswa. Jurnal Penelitian Ipteks, 3(1), 86-99.

Tedjo, M., Sugito., Santoso, R. (2017). Analisis faktor-faktor yang mempengaruhi keputusan penggunaan transportasi pribadi pada mahasiswa menggunakan pendekatan partial least square. Jurnal Gaussian, 6(2), $211-219$. https://doi.org/10.14710/j.gauss.v6i2.16950

Turniasih, I., \& Dewi, N. K. (2016). Peranan sektor agroindustri dalam pembangunan nasional. Jurnal Geografi Gea, 7(2), 1-8. https://doi.org/10.17509/gea.v7i2.1723.g1173

Zaiţ, A., \& Bertea, P. (2011). Methods for testing discriminant validity. Management \& Marketing Journal, 9(2), 217-224.

Zulaifah, S. (2006). Pemanfaatan sumberdaya hutan bersama masyarakat untuk pengembangan kawasan Hutan Regaloh di Kabupaten Pati Jawa Tengah [Thesis]. Universitas Diponegoro. 